\title{
Recruitment and Selection Model Lecturer Based on Islamic Boarding Schools
}

\author{
Apriyanti Widiansyah, Sutjipto, Mukhneri Mukhtar
}

\begin{abstract}
The research aims to know the pattern of recruitment and selection lecturer based boarding schools, Ethnographic studies conducted at the Institute of Shalahuddin Al-Ayyubi (INISA) at boarding schools El-Nur El-Kasysyaf in West Java Indonesia. Looking at the at some of these data, can be inferred that, there are the findings obtained with regard to Recruitment lecturer at INISA, encompasses: 1) Recruitment is done through the acceptance of permanent lecturer mutations, i.e. accept prospective lecturers from the outside to be a lecturer in INISA environmental; 2) Recruitment lecturers through a system of contracts, i.e. by lifting some of the lecturers with expertise specific and special needs for the contracted as Lecturer INISA or as Chairman, within a certain period; 3) Recruitment lecturers is done with requests for assistance to the College, government agencies, or private institutions, to submit resources with specific skills to teach in INISA; 4) Recruitment conducted by recruiting lecturers from the outside or in the campus of INISA, is then placed as adjunct faculty at each honorary lecturer status normal. Based on some of these data, it can be concluded that there are several findings obtained with regard to the selection of lecturers in INISA, among them: 1) Selection of the lecturers remained relatively tight, but not for adjunct, because selection is only done through interviews, but in the number of adjunct lecturers far more from fixed; 2) The system of selection less support for the election of a candidate lecturer skilled in learning appropriate fields are pursued, since the material test consists of General knowledge, knowledge of religion, Arabic, English, and a psychological test, and there are no tests that test the ability of the prospective lecturers in their respective fields
\end{abstract}

Index Terms: Recruitment Model, Selection Lecturer, Islamic Boarding Schools.

\section{INTRODUCTION}

The College has an important role in the development of the nation and is a means to print the student's intellectual property in an attempt to organize the life of the nation is heading in the direction of better. In organizations, corporations or institutions work, the factor of human resources holds the most important role, including in the College known as the professions of Lecturer.

One of the challenges for universities in particular human resources management is a professional lecturer present, where the College was able to produce graduates competent in their fields. To obtain prospective lecturers, the College

Revised Manuscript Received on April 19, 2019.

Apriyanti Widiansyah, Educational Management, Faculty of Education, Jakarta State University, Jln Rawamangun Muka, Rawamangun Pulogadung East Jakarta City, DKI Jakarta 13220

Sutjipto, Educational Management, Faculty of Education, Jakarta State University, Jln Rawamangun Muka, Rawamangun Pulogadung East Jakarta City, DKI Jakarta 13220.

Mukhneri Mukhtar, Educational Management, Faculty of Education, Jakarta State University, Jln Rawamangun Muka, Rawamangun Pulogadung East Jakarta City, DKI Jakarta 13220. can do the process of recruitment and selection is good.

As for the benefits of recruitment and selection is function as "select candidates right and proper position", it becomes a handle for the institutions in putting prospective lecturers at colleges by having some criteria of which; have great skill, willingness to work, there are rewards, and have hope in the future. Optimal performance will be realized when the institutions can select workers who have the motivation and skills to suit his job, as well as having a condition that allows working to its full potential.

Presence and intelligence resources management lecturer has an important role and participates to determine fluency and College success. The efforts of lecturers can carry out tasks properly and effectively then sued to have the ability, work motivation, discipline, work ethics, work culture, work ethic, and high morale.

One of the secondary boarding schools in the world that are experiencing significant development was education at the college level. College in boarding schools is essentially an ideal institution of higher education that blends a variety of excellence the College's General and boarding schools.

Values in higher education in a boarding school can be called with the boarding school characteristics. The characteristics of higher education in a boarding school in between; First, the value of sincerity is very high, so that student learning is not only because the student's demands of employment or a diploma course, unless compelled by the existence of a duty that is, humans are obligated lifelong study. Second, the values of self-reliance have a strong spirit of students to live independently. Third, onboarding environment supervising boarding school and students live in the neighborhood blends. Fourth, in taking policy, supervising boarding schools put more emphasis on the things that are of the family are normative or rules of the organization. Fifth, the value of the boarding schools education not just theory but put more emphasis on the implementation of a good role model. (1)

As the development of the emergence of diverse community needs in Indonesia, it would trigger an increase in the needs of the community will be higher education institutions, especially in West Java with a case study on the Institute Islam of Shalahuddin Al-Ayyubi (INISA) at boarding schools El-Nur El-Kasysyaf Bekasi as objects of study, so that it can be easily reached by all walks of life. The existence of some Islamic College Private based boarding school certainly is a form of real commitment from boarding school to keep providing educational services is 
optimal for the whole community.

There is fairly large community interest, it would certainly be a challenge not only for all of the academic colleges in INISA, do not let the West Javanese expectations will be the birth of a generation of educated intellectuals and religious, lost because the management of learning that is not professional. Therefore, the College gradually INISA requires an increase in the quality of higher education, so as to provide optimal and professional education services. What's with the demands of the times and a rapidly growing, highly unexpected presence of Islamic College was so trusted by the community, just print out the educated unemployment.

Refer to the condition, then boarding school El-Nur ElKasysyaf (YAPINK) Bekasi later decided to set up colleges of INISA, to meet the needs of the community of higher education institutions, so that students can continuing education at colleges that are in the shade of the boarding school. Based on a few things, then the researcher is driven to do further studies on the management of College-based boarding school. In focus on the resources a lecturer at an Institute Islamic of Shalahuddin Al-Ayyubi (INISA) Bekasi West Java Indonesia. The focus of the research outlined became the focus of the research the following sub; 1) Recruitment of Lecturers at the Institute of Islamic Shalahuddin Al-Ayyubi (INISA); 2) Selection of Lecturers at the Institute of Islamic Shalahuddin Al-Ayyubi (INISA).

\section{LITERATURE REVIEW}

\section{A. Recruitment}

Recruitment is the generation of an applicant pool for a position or job in order to provide the required number of candidates for a subsequent selection or promotion program. Recruitment is done to achieve management goals and objectives for the organization and must also meet the current legal requirement (human right, employment equity, labor law, and other legislation. (2) Rynes and Boundreau (1986) defined recruitment as "All organizational practices that affect either the number or types, of individuals that are willing to apply for, or to accept, a given vacancy". Barber (1998) similarly defined recruitment as "Including those practices and activities carried on by the organization with the primary purpose of identifying and attracting potential employees". (3)

Breaugh (2008) Recruitment is critical to organizational success, and that employee recruitment has become a highly discussed topic in recent years. According to Breaugh \& Starke (2000), recruitment is a set of activities which organizations accomplish in order to find the right people for their vacancies, the primary mechanism to attract potential employees. (4)

As explained by Opatha (2010) recruitment is the process of finding and attracting suitably qualified people to apply for job vacancies in the organization. It is a set of activities an organization uses to attract job candidates who have the needed abilities and attitudes. (5) A recruitment process is a tool that the company uses in order to gain the needed resources. It involves the selection of future workers out of the candidates who possess the appropriate qualities and skills required by the organization. (Jamka, 2011) The recruitment process is an ongoing procedure that applies to specific time which somehow forces the company to undertake an adequate preparation. (6)

Sangeetha (2010) opined that the recruitment process involves the sourcing, advertising and interviewing of future employees, however, the selection process entails the staffing and training of new employees on the role of their new job. An Organization needs careful time and consideration to sustain competitive advantage in developing a strategy on recruitment and selection process. Decisions made in the recruitment and selection process or stage will impact the company in the future. (7) Work by Silzer et al (2010) the process of recruitment does not cease with the application of candidature and selection of the appropriate candidates but involves sustaining and retaining the employees that are selected. (8)

The recruitment process should inform qualified individuals about employment opportunities, create a positive image of the company, provide enough information of the jobs so that applicants can make comparisons with their qualifications and interests, and generate enthusiasm among the best candidates so that they will apply for the vacant positions. (9)

Methods of recruiting employees with proper competence can be divided into two basic types: external recruitment and recruitment within the organization. Depending on which type of recruitment an organization decides to engage in, there are various tools to choose from. Every organization may carry out a simultaneous process of external and internal recruitment or may decide to carry out only one of those. Some companies in principle choose to recruit from within the company in the initial phase of recruitment.

\section{B. Selection}

According to Yaseen (2015) Selection is the second stage of the employment process. Selection is, therefore, the process of identifying the most appropriate and suitable person for a particular job. Through selection, the performance for the job is predicted and applicants must fulfill this performance requirement before they would be selected. (10)

Gupta (2006) observes that selection can be conceptualized in either choosing the "fit" candidates or rejecting the candidates, or a combination of both. Selection process assumes rightly that there are more candidates than the number of job openings available (Prasad, 2005). The basic idea in the selection process is to solicit maximum possible information about the candidates to ascertain their suitability for employment and given the fact that there are factors which affect the seeking of such information (Graham, 1996) (11)

The selection is a process of selecting qualified individuals to fill vacancies in the organization. In other words, the organization would have little chance of success if it fails to select people with the necessary qualifications because the main goal is to hire the best person which is a fundamental principle of the laws on equal employment 
opportunities. It is very important to perform the selection in a transparent way as it is considered that even the best training of candidates cannot replace poor selection. Subsequently, each organization must previously identify its tasks, abilities, and skills, but also to determine the selection criteria. (12)

Walker (2009) Some of the processes in selection include screening applications and resumes, testing and reviewing work samples, interviewing, checking references and background. Organizations use these processes to increase the likelihood of hiring individuals who possess the right skills and abilities to be successful in their jobs. (13)

Selection involves the use of one or more methods to assess an applicant's suitability in order to make the correct selection decision. Selection can be alternatively seen as a process of rejection as it rejects a number of applicants and selects only a few applicants to fill the vacancy. Thus, selection function may be a negative function rather than a positive function. The objectives of selection function are to get the right person to the right job, establish and maintain a good image as a good employer, and maintain the selection process as cost-effective as possible. (14)

The selection of implementation measures needs to be carefully defined and based on the principle of efficiency to obtain qualified employees with proper placement. Here are the steps the selection i.e. 1) Acceptance of cover letter; 2) Conducting the test; 3) Selection Interview; 4) Checking the background and reference documents of applicants; 5) Health evaluation; 6) Live interview by the Manager; 7) Decision on application. (15).

\section{Lecturer}

A lecturer is someone who based on education and expertise is appointed by the organizers of higher education with the main task of teaching at the relevant university. The lecturer category includes ordinary lecturers, extraordinary lecturers, and guest lecturers. Regular lecturers are lecturers who are appointed and placed as permanent staff in the relevant university. Extraordinary lecturers are lecturers who are not permanent staff at the relevant university. A guest lecturer is someone who is invited to teach at a university for a certain period of time.

The academic level of the lecturer basically consists of assistant experts, lecturers, chief lecturers, and professors. Authority and procedure for the appointment and dismissal of academic positions are regulated in accordance with the applicable legal provisions. (16)

Educators (teachers and lecturers) are educational resources that have a central position. This is because the role of educators is very strategic in achieving educational goals. Therefore, even though other educational resources are sufficient, it will be meaningless if managed by creative competent educators, the educational goals can be achieved. To obtain competent teachers and lecturers, it is necessary to pay attention to the recruitment process. The process of recruiting teachers and lecturers does not only fill the shortcomings but also aims to improve the quality of education.

The authority and competence of teachers and lecturers are evidenced by minimum academic education qualifications and certification. The minimum qualification for academic education for TK / RA / TKLB level teachers, SD / MI, SMP / MTs, SMA / MA, SMK / MAK is D-IV or $\mathrm{S} 1$ graduates. While the minimum academic education qualifications for lecturers are (1) graduates of the master's program for diploma and undergraduate programs; and (2) graduates of doctoral programs for postgraduate programs. (17)

Lecturers are an important parameter in the process of controlling higher education institutions because of their very central position, placing lecturers as the main HR holders of operational duties and responsibilities of universities. With professional skills and close relationships with students and colleagues, lecturers greatly determine the development of institutions, influencing the intellectual and social environment of campus life. Therefore, all efforts made with the aim of improving the performance of lecturers as teaching staff in higher education in a comprehensive manner need to be done so that their functions and roles can be carried out optimally in order to achieve organizational goals. (18)

The effectiveness of organizational changes in the field of education requires the support of all existing HR (Human Resources), especially the commitment of each member to change. HR in education includes lecturers, administrative staff and functional staff other than lecturers (researchers, librarians, and archivists). HR development efforts need to touch all HR elements. Of the three elements, the lecturer has a very strategic and important role. HR lecturers have a vital position in shaping the quality of graduates. This is reinforced by the reality that the highest authority and authority in the academic process resides in the lecturer HR. (19)

(Sudiana, 2003) put forward to improve the quality of the learning process in college, demanded an increase in the professionalism of lecturers. Lecturer as one component of the college very large role in realizing the quality of higher education itself. To that end, the lecturer is always required to follow the development of knowledge, both with regard to the field of study (subject matter) as well as with regard to pedagogic. Based on this standard of professionalism lecturer pointed out that some private college lecturers, especially in the province of West Java Indonesia do not have a professional quality. Where many lecturers college graduates, so it can be said of many Lecturers do not meet the professional standards that impact the performance of the college. (20)

\section{Islamic boarding schools}

Pesantren (boarding school) is a place where students and Islamic teacher/kiyai or his representative learn formally, non-formally, and informally whether in the morning, at noon, or in the evening. Pesantren has been proven successful in educating their students and creating charismatic and high-quality scholars and religious leaders. It is due to the effective teaching methods they develop in which focusing on personal guidance by the kiyai (teachers) and students' qualitative comprehension instead of merely the cognitive aspects through lecturing. (21) 
Boarding school is a religious Islamic institution which organizes community-based primary education are integrated with other types of education, aims to develop the abilities, knowledge, and skills of learners to become an expert of religion ( $f \grave{\imath}$ mutafaqqih al-dīn) or being a Muslim who has the skills or expertise to build the lives of Islamic community. (22)

Boarding sense etymologically derived from Persia or India i.e. Shastri means the person being studied. There is a possibility that Shastri said then translated into the Java language into Students, thus the place inhabited by students called boarding schools, which means a place of learning. (23)

While in the terminology boarding school known as "sincerity" in contrast to sincerity is known outside the community, the environment contains the sense of sincerity in accepting, giving and doing something in between fellow creatures. (24)

The types of boarding school consist of Salafiyah and Khalafiyah. Salafiyah is a traditional boarding school type still exists up to now and retaining teaching textbooks of classical Islam (the Yellow Book) without teaching public lessons, even though it has adopted methods teaching schools. While Khalafiyah is a boarding school with religious lessons and General taught side by side. In addition, adopt a tiered class system and lessons in the classroom. (25)

Curriculum Salafiyah (traditional) generally only teach classic books (the Yellow Book) include; monotheism, Tafsir, Fiqh, Usul Fiqh, Tasawuf, Arabic (Nahwu, Shorof, Balaghah, and Tajwid), Mantiq and morals. Because there is a diversity of subject matter content levels of difficulty, then the execution of the boarding school education curriculum and then given the rank, i.e. stages ride books or taking a class. While the curriculum of Khalafiyah (modern) has been modified and adapted to the needs of the present on the basis of several factors, including 1) Consideration of institutional construction under the Ministry of Religion in the context of a modern boarding school, in addition to maintaining the tradition of teaching Islamic sciences, also adopted the pattern of a curriculum developed by the Ministry of Religion i.e. national curriculum; 2) Considerations associated with contextual business Islamicoriented education to address the challenges of the present and the future. (26)

Boarding school as a system has four essential elements in the process of managerial related. These elements are: First, Kiyai as caretakers, owner, and handler of boarding; Second, students learn the knowledge of pupils, namely the Islamic to Kiyai; Third, i.e. a system including the dormitory mosque; Fourth, that the Yellow Book (al-kutub ashshafra). (27)

Whereas the purpose of education boarding school is forming a human being who has a high awareness that Islamic teachings are comprehensive. In addition, the seminary was also constructed to have high abilities in responding to the challenges and demands of life in the context of space and time, in the realm of National or International.

The hope of the creation of a young generation of Muslims with moral character and virtue based on the values of Islamic teachings and Muslim intellectuals that lack knowledge is a reference for Islamic boarding schools in the process of education and teaching to santri.

From the reviews above, it can be concluded that Islamic boarding schools are a traditional Islamic educational institution that carries the mission of maintaining and spreading the values of Islamic teachings, using a dormitory system under the guidance of the kiyai as a leader, as well as teaching santri in Islamic boarding schools, mosques as a central point the information and activities of the santri, as well as the teaching of Islam as the core of the activities carried out by the santri, with their functions as da'wah institutions tasked with transferring Islamic knowledge and maintaining Islamic traditions by providing guidance to prospective ulama, to achieve the ultimate goal of continuing values cultural and religious values by printing and cadre ulama and young kiyai. With the foundation of devotion to Allah SWT, it is the ultimate goal of Islamic education.

\section{METHODOLOGY}

The research uses a qualitative methodology, with ethnographic studies. Ethnographic models are studies to describe a culture in a place. The model seeks to study cultural events, presents the life view of the subject as the object of study. Ethnographic studies related to the subject of thinking, life, and behavior. Therefore, it is necessary to choose unique events and rarely observed by most people.

Ethnographic research is an activity to collect information material or data carried out systematically on the way of life and various social-cultural activities of a community. Unique events and events from the cultural community will attract the attention of ethnographic researchers. Researchers learn more from cultural owners. Therefore, observation by being directly involved becomes important in research activities.

Ethnography basically uses participant observation data. This is in line with the understanding of ethnographic terms derived from the ethno word (nation) and graph (describing or describing). Ethnography is a variety of exposure to cultural research to understand how people interact and collaborate through phenomena observed in everyday life. (28)

An ethnographer is not enough to only meet with research subjects for one or two times, as is the tradition of quantitative research using questionnaires arranged as instruments. Ethnographers are researchers who are part of the community under study, while still having a position as researchers.

This research basically is a research activity to collect data, present information to then describe a situation that occurs in the field, regarding "Model of Recruiting and Selection of Islamic Boarding School Based Lecturers with INISA case studies in Islamic boarding schools in El-Nur El-Kasysyaf Bekasi Java West Indonesia." Then draw conclusions based on the stipulated provisions.

To obtain data about Recruitment and Selection Model 
Lecturer at INISA, researchers made plans to collect data using the following data / research techniques: 1) Observation, The author conducts data collection with participant observation techniques, by doing direct activities in the process writing activities; 2) Interview, in obtaining data and information needed, the author conducted an interview on research subject. Informant at the interview these are education practitioners; 3) Literature, The library method is used as a method in collecting data, because it can increase the author's knowledge of the theories that support research; 4) Documentation, to complete the study, the author using data collection techniques in the form of Documentation. (29)

Thus, the author uses the method qualitative ethnography, which describes it clear cultural dimensions of the object of research regarding Recruitment and Selection Model Lecturer Based Islamic Boarding Schools based on the objective, as well as describing the condition of the subject/object based on the facts studied

\section{RESULT AND FINDING}

A. Recruitment of Lecturers at the Institute Islamic of Shalahuddin Al-Ayyubi (INISA)

The need for a permanent lecturer in INISA was very high, especially on some public courses, while the addition of a permanent lecturer rations also is limited by the Coordinator of the private Islamic Colleges, then recruitment against adjunct be findings that more interesting, due to recruitment against lecturers still have become the responsibility of the Coordinator of the private Islamic Colleges, so the pattern is relatively constant. In meeting the needs of lecturers, INISA hiring lecturers with several methods, i.e. through mutation, contract, partnership, and the appointment of an honorary lecturer.

\section{The first method,}

permanent lecturer Recruitment is done through the acceptance of the person that the mutation, that accepts people from outside of INISA to become a lecturer in environmental energy INISA. Mechanism of recruitment of lecturers through mutations, performed by the respective faculty asked to move into a level. The recommendations of each faculty are required to ascertain whether or not according to your needs, and acts "qualify need" is defined based on the results of the Faculty Senate meeting.

Recalling the Senate on nearly all faculty covered by lecturers who come from a certain organization, then the shades that look is the organization which background a factor of consideration, the decision was taken based on the leadership meeting Faculty submitted to the level of the Institute, so that the element is not visible, although primordialism will be slightly hampered at the time of the interview with the Institute.

\section{The second method,}

the Recruitment system through contract lecturers i.e. by lifting some of the lecturers, people who have certain skills, a rare and much-needed, for contracted as lecturers or as power Chairman, in a period of certain. Recruitment of lecturers with a system of contracts, including a new method in the new environment of INISA, as was done at the time of
INISA require lecturer at several faculties, both lecturers at public or religious subjects.

\section{The third method,}

Recruitment is done through the help of lecturer collegiate institutions, government agencies, or private institutions, to submit resources specific skills lecturer to teach in INISA. Recruitment cooperation system with the lecturer is not a new thing in an environment of INISA, only cooperation is done more to higher education institutions abroad, such as the Al-Azhar University of Cairo and a few other colleges so that It is been a long time INISA have guest lecturers that came from the College. The difference with the condition now that cooperation is also done with a couple of INISA institution and non-local in the country, to send the resource became a lecturer at INISA. Lecturers are hired with the third method, being adjunct requirements with visiting lecturer and honorary lecturer with incentives different from ordinary, honorary lecturer with the consideration of the special skills that are owned.

\section{The fourth method,}

Recruitment is done with a compelling lecturer from the outside or in the campus of INISA to be placed as adjunct faculty at each honorary lecturer status normal. Internal recruitment is done to meet the needs of lecturers with expertise the common lot of INISA, while Professor owned recruitment externally, made to meet the needs of a lecturer with special skills that are not owned by the lecturer INISA, so that more recruits from among the professional. The fourth method is based on the amount, there are quite a lot of INISA lecturer who is still on the particular, but being a Faculty adjunct faculty on the other, so difficult to find accurate data about the number of adjunct owned by each faculty, because quite a lot amount of INISA lecturer who taught more than one faculty.

\section{B. Selection of Lecturers at the Institute Islamic of} Shalahuddin Al-Ayyubi (INISA)

As part of the College-based boarding school that is under the coaching Coordinator College of Islamic studies, the selection of lecturers is a series of activities in energy procurement environment of INISA to date. Based on the data in the last few years, which corroborated with information from multiple information sources, the selection of prospective lecturers INISA was done through three stages.

The first phase, the selection is done by examining some of the administrative requirements, as requested in the recruitment announcement lecturer. The second phase, the selection is done by giving a written test include: Test of General knowledge, Knowledge of religion, and academic Potential Tests include United Kingdom, Arabic Language, and a psychological test. The third stage, a test interview given to participants who pass a test first and second stage.

According to several sources who have been following the test at INISA, in stage interviews are often used for the search process background information organization 
religious student or prospective professors, so there is rarely a participant failed the test selection due to the lack of background rendering organizations prospective lecturer with the Organization INISA surroundings.

The selection process is so tight, it turns out that the only permanent lecturer, while for adjunct professors is only done through the selection interview process of the respective Dean about the commitment to teach at INISA.

The decision is accepted or fabricated prospective adjunct to teaching at INISA was officially established on the basis of the results of the meeting of the Faculty Senate, although the initial decisions taken on the recommendation of the Chairman of the course or the Dean of the Faculty.

With regard to the decision-making process at the level of the Faculty Senate, the background of prospective adjunct organizations often becomes a consideration, so the background of someone who recommended be special consideration in decision making.

A Selection process for the adjunct in INISA does not make a person's competence factor as a major factor in decision-making, although at some faculties student complaints about adjunct are more due to factors less presence.

Though the Lecturer still has weaknesses such as mentioned above, in particular in the selection of prospective lecturers anyway, if viewed from a report on the list of participants who passed the selection test, the quality of the graduation of the selection a lecturer INISA good enough.

The consortium of science is an institution consisting of experts in various fields of science specifications. According to Provost Academics, plan the formation of the Science Consortium was being forged, there is only used for selecting prospective lecturers, but also used to evaluate lecturers who are already teaching, so it is not close is likely to occur where a lecturer redirected to the Administration, if the appearance and competency assessed by the consortium of science do not fit to become a College Lecturer.

To be able to judge a college lecturer has competency in learning or not, then the Faculty formed a consortium of science include the science of Tafseer, Hadith science, the science of Kalam, philosophy, and history of Islamic civilization. In addition, there is also a consortium of educational courses, namely in Arabic.

The Consortium has the following tasks: 1) Foster Assistant Expert to get a functional Office Associate, included in the test of the ability of the new lecturer; 2) Discussion on internal study program; 3) Do scientific research as well as community services; 4) Commissioned the creation of journal and book materials. However, these tasks are not yet fully implemented, particularly in testing the ability of new lecturers, as there are some constraints with regard to the matter of time.

Based on the foregoing, it can be concluded that the function of the Consortium lecturer based on fields, is as a tool to ensure the quality of professors, especially with regard to academic quality. Although the Consortium's functions within the competence of the new professors have not been fullest, for other functions of the majority is already running

\section{CONCLUSION}

Looking at the at some of these data, can be inferred that, there are the findings obtained with regard to Recruitment lecturer at INISA, encompasses: 1) Recruitment is done through the acceptance of permanent lecturer mutations, i.e. accept prospective lecturers from the outside to be a lecturer in INISA environmental; 2) Recruitment lecturers through a system of contracts, i.e. by lifting some of the lecturers with expertise specific and special needs for the contracted as Lecturer INISA or as Chairman, within a certain period; 3) Recruitment lecturers is done with requests for assistance to the College, government agencies, or private institutions, to submit resources with specific skills to teach in INISA; 4) Recruitment conducted by recruiting lecturers from the outside or in the campus of INISA, is then placed as adjunct faculty at each honorary lecturer status normal.

Based on some of these data, it can be concluded that there are several findings obtained with regard to the selection of lecturers in INISA, among them: 1) Selection of the lecturers remained relatively tight, but not for adjunct, because selection is only done through interviews, but in the number of adjunct lecturers far more from fixed; 2) The system of selection less support for the election of a candidate lecturer skilled in learning appropriate fields are pursued, since the material test consists of General knowledge, knowledge of religion, Arabic, English, and a psychological test, and there are no tests that test the ability of the prospective lecturers in their respective fields.

\section{ACKNOWLEDGMENT}

In the process of this research, researchers like to thank parents, husband, promotor and co-promotor, friend and also to the research place at Islamic religious Institute of Shalahuddin Al-Ayyubi (INISA) at boarding schools El-Nur El-Kasysyaf Bekasi. With the support whether material and non-material that had been sent a researcher of the completion of this research. Finally researchers hope that this research can give benefits for science development, readers, as well as the researchers.

\section{REFERENCES}

1. Halil M, Anwar MA. Inovasi Manajemen Universitas Pesantren Tinggi Darul Ulum Sebagai Perguruan Tinggi Alternatif Bagi Masyarakat. Manaj Pendidik Islam. 2016;2(1):2527-6190.

2. Victor M. Catano, Willi H. Wiesner, Rick D. Hackett LLM. Human Resource Management: Recruitment and Selection in Canada. 4th ed. Monica Belcount, editor USA: Nelson Education, Ltd.; 2010. 3 p.

3. Oxford Library of Psychology. The Oxford Handbook of Recruitment. Kang Yang Trevor YU \& Daniel M. Cable, editor. New York: Oxford University Press; 2014. 185 p.

4. Mohammed F. Deployment of Social Media in the Recruitment Process. J Knowl Manag Econ Inf Technol 2015;V(1):1-24.

5. Ekwoaba JO. THE IMPACT OF RECRUITMENT AND SELECTION CRITERIA ON ORGANIZATIONAL PERFORMANCE. Glob J Hum Resour Manag. 2015;3(2):22-33. 
6. Ślusarczyk B. GR. The Recruitment Process In Transnational Corporations. POLISH J Manag Stud. 2014;10(1):189-97.

7. Development E, Ogbu OJ, Remilekun OG. Impact of Recruitment and Selection Strategy on E mployees Performance: A Study of Three Selected Manufacturing Companies in Nigeria. Int $\mathbf{J}$ Innov Econ Dev. 2017;3(3):32-42.

8. Karthiga MG, Karthi R, Balaishwarya MP. Recruitment and Selection Process. Int J Sci Res Publ. 2015;5(4):1-4.

9. V. T. Shailashri SS. STUDY TO IDENTIFY THE RELATIONSHIP BETWEEN RECRUITMENT SELECTION TOWARDS EMPLOYEE ENGAGEMENT. Int $\mathrm{J}$ Sci Res Mod Educ. 2016;I(II):149-55.

10. Otoo IC, Agyei PM. Effectiveness of Recruitment and Selection Practices in Public Sector Higher Education Institutions: Evidence from Ghana. Eur Sci J. 2018;14(13):199-214.

11. Kepha O, Mukulu E, Waititu A. The Influence of Recruitment and Selection on the Performance of Employees in Research Institutes in. Int J Sci Res. 2014;3(5):132-8.

12. Stoilkovska A, Ilieva J, Gjakovski S. EQUAL EMPLOYMENT OPPORTUNITIES IN THE RECRUITMENT AND SELECTION. UTMS J Econ. 2015;6(2):281-92.

13. Saviour AW, Kofi A, Yao BD, Kafui LA. The Impact of Effective Recruitment and Selection Practice on Organisational Performance (A Case Study at University of Ghana). Glob J Manag Bus Res A Adm Manag. 2016;16(11).

14. Aruna S. Gamage. Recruitment and Selection Practices in Manufacturing SMEs in Japan: An analysis of the link with business performance. Ruhuna J Manag Financ. 2014;1(1):37-52.

15. Heru Soesanto. Proses Rekruitmen dan Seleksi pada PT. Berkat Sejati Jaya. Agora. 2015;3(2):489.

16. Bastian I. AKUNTANSI PENDIDIKAN. Yogyakarta: Erlangga; 2006. 30 p.

17. Mintarsih Danumiharja. Profesi Tenaga Kependidikan. Yogyakarta: Deepublish; 2014. 83 p.

18. Petrus Nyavon. Pengaruh Kinerja Dosen dengan Motivasi Belajar pada Mahasiswa Prodi Sosiatri Fakultas Ilmu Sosial dan Ilmu Politik Universitas Mulawarman. ejournal.psikologi.fisip-unmul.ac.id. 2017;5(2):137-46.

19. Erika Setyanti Kusumaputri. Komitmen pada Perubahan Organisasi (Perubahan Organisasi dalam Perspektif Islam dan Psikologi. Yogyakarta: Deepublish; 2015. 31-32 p.

20. Fanggidaea RE. YS, Efendic N, Hilmiana. Effect of a Spirituality Workplace on Organizational Commitment. In: Procedia - Social and Behavioral Sciences. Malaysia: Elsevier Ltd; 2016. p. $639-646$.

21. Abdurrahman NH. CHARACTER EDUCATION IN ISLAMIC BOARDING SCHOOL- BASED SMA AMANAH In a society where there is degradation of values and morality, it is the right moment to revive character education. Public, $s$ support to its implementation in schools is clearly express. 2016;2(2):287-305.

22. Paturohman I. PERAN PENDIDIKAN PONDOK PESANTREN DALAMPERBAIKAN KONDISI KEBERAGAMAAN DI LINGKUNGANNYA (Studi Deskriptif pada Pondok Pesantren Dār Al-Taubah, Bandung). Tarbawi. 2012;1(1):65-74.

23. Syam N. Islam Pesisir. Yogyakarta: LkiS; 2005.74 p.

24. Wahid A. Menggerakkan Tradisi: Esai-Esai Pesantren. Yogyakarta: LkiS; 2001. 8 p.

25. Latif Y. Intelegensia Muslim dan Kuasa: Genealogi Intelegensia Muslim Indonesia Abad Ke-20. Bandung: PT. Mizan Pustaka; 2005. 239 p.
26. Rumadi. Renungan Santri: Dari Jihat Hingga Kritik Wacana Agama. Jakarta: Erlangga; 2007. 126-127 p.

27. Ali Maschan Moesa. Nasionalisme Kiai: Konstruksi Sosial Berbasis Agama. Yogyakarta: LkiS; 2007. 94-95 p.

28. Endraswara S. Metode, Teori, Teknik: Penelitian Kebudayaan (Ideologi, Epistemologi dan Aplikasi. Sleman: Pustaka Widyatama; 2006. 207-208 p.

29. Widiansyah A. Pengendalian Mutu: Implementas Manajemen Sumber Daya Manusia, Optimalisasi Fungsi Pengendalian Dalam Dunia Pendidikan. Cakrawala Hum Univ Bina Sarana Inform. 2019;2(2):21-6.

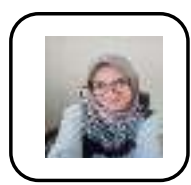

\section{AUTHORS PROFILE}

Apriyanti Widiansyah who is a Permanent Lecture at the Faculty of Education at Bhayangkara University, Greater Jakarta. Currently completing Doctoral (S3) Education Management Study Program at the Jakarta State University and currently in the process of writing a Dissertation.

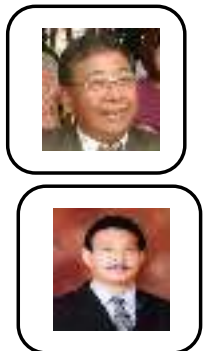

Sutjipto who is a Professor at the Jakarta State University in the field of concentration in Education Management.

Mukhneri Mukhtar is a Professor at the Jakarta State University in the field of concentration in Education Management. 